\title{
CONSISTENCY OF INSTRUCTIONAL STRATEGIES IN CONTROLLING STUDENTS' DISCIPLINE IN THE COVID-19 PANDEMIC ERA
}

\author{
Astrid Wangsagirindra Pudjastawa, Helmy Bastian \\ SMKN 3 Malang Jawa Tengah, Indonesia \\ Email: a.w.pudjastawa@gmail.com, helmybastian1@gmail.com \\ Received: 2021-02-15; Accepted: 2021-02-30; Published: 2021-03-10
}

\begin{abstract}
Educational Institutions have been closed around the world due the COVID-19 outbreak. This article aims to describe the results of exploring learning strategies applied at SMKN 3 Malang in the era of the COVID-19 pandemic. This Learning Strategy can help run online teaching in schools. The development of this method departs from researchers' desire to give birth to online teaching methods in the form of qualitative descriptive. Researchers observe and focus fully on students' disciplinary behavior in the classroom rules and procedures consistently applied by educators during the learning process. Data collection was carried out through observation, interviews, and documentation. The results showed that students showed consistent attitudes in (1) readiness to learn, (2) cooperation, and (3) independence. Several factors influence success in maintaining consistency in implementing the applied learning strategies, among others; asking students to become moderators who accompany the teacher, distribution of tasks and intensive mentoring for each group member and maintaining two-way learning through regular evaluation and reflection.
\end{abstract}

Keywords: Covid-19; instructional strategies; online teaching

\begin{abstract}
Abstrak
Institusi pendidikan telah ditutup di seluruh dunia karena wabah COVID-19. artikel ini bertujuan untuk mendeskripsikan hasil eksplorasi strategi pembelajaran yang diterapkan di SMKN 3 Malang pada era pandemi COVID-19. Strategi pembelajaran ini dapat membantu menjalankan pengajaran online di sekolah. Pengembangan metode ini bertolak dari keinginan penulis untuk melahirkan metode pengajaran online. Metode penelitian yang digunakan dalam bentuk deskriptif kualitatif. Penulis mengamati dan memfokuskan sepenuhnya pada perilaku disiplin siswa dalam aturan dan prosedur kelas yang diterapkan secara konsisten oleh pendidik selama proses pembelajaran. Pengumpulan data dilakukan melalui observasi, wawancara, dan dokumentasi. Hasil temuan menunjukkan bahwa siswa menunjukkan sikap konsisten dalam (1) kesiapan belajar, (2) kerjasama, (3) kemandirian. Beberapa faktor yang mempengaruhi keberhasilan dalam penerapan strategi pembelajaran yang diterapkan antara lain; meminta siswa menjadi moderator pendamping guru, pembagian tugas dan pendampingan intensif untuk setiap anggota kelompok, serta menjaga supaya pembelajaran yang dilakukan menggunakan model pembelajaran dua arah melalui evaluasi dan refleksi secara berkala.
\end{abstract}

Kata Kunci: Covid-19; strategi intruksional; pengajaran online

\section{INTRODUCTION}


The coronavirus called COVID-19 was officially declared a pandemic by WHO on March 12, 2020 (WHO, 2020) COVID-19 is a severe acute illness that can cause respiratory syndrome and is a type of virus. The closure of educational institutions occurred due to this pandemic. An estimated 107 countries implemented the closure of educational institutions. It can be said that this pandemic has affected 862 million people across students. That is roughly calculated as half of the world's student population (Viner et al., 2020) In addition, 29 countries closed their educational institutions a week before the official announcement (UNESCO, 2020). The closure of educational institutions is a major consideration due to this pandemic. That is because many assumptions have emerged that minimizing social contact can reduce influenza outbreaks (Jackson et al., 2016).

The COVID-19 pandemic has also affected education in Indonesia. Many schools from primary to tertiary level are switching from traditional face-to-face education to distance education. Most of the educational institutions are moving exclusively towards online education. Students get an online education by sitting in front of their computer screen or smartphone. This article discusses the impact of online education on SMKN 3 Malang as an educational institution in Indonesia. Furthermore, the researcher also suggests a method, which will be useful in distance learning. This method will be tested, and the results will be described in this paper.

For SMKN 3 Malang, moving from face-to-face learning to distance learning is a challenging task. That is because both teachers and students must be forced to transform to distance learning in the shortest possible time. As an educational institution located in a developing country area, technological progress has not been done much. Learning plans, teaching materials (audio and video), relevant software, special installations, and technology support are mandatory steps for implementing distance learning. Although today's students are still close to technology, this is a serious challenge.

One of the problems that often arise was that students and teachers did not have sufficient resources for online education. Furthermore, literature proved that the lack of IT infrastructure was a major problem in distance learning (Rafiq, 2020). Another significant problem was the lack of IT knowledge of teachers and school management; they also lacked of electronic devices (Rafiq, 2020). Some students also reported being unable to do distance learning due to poor internet service (Muslimin \& Harintama, 2020).

In addition to the problems above, another problem was the diversity of student abilities (diversity learners) in a class. Some easily absorbed the material, but some took longer to understand the subject matter. The ability to absorb diverse materials causes teachers to be faced with two difficult choices. On the one hand, students with limited intellectual abilities needed intensive repetition and mentoring, but at the same time, other students needed additional material. Gerber argued that in classrooms with diverse needs and limited infrastructure, teachers were not able to optimize learning to suit the diverse characteristics of students (Weisel \& Dror, 2006).

Another toughest challenge that must be faced was that schools in Indonesia, including SMKN 3 Malang, were limited in the number of "ideal" teachers. The serious consequence that arise from this was that there was often an overload of workload on 
the teacher concerned so that the teacher's function as educator, facilitator, observer, diagnostician, counselor and leader in the classroom did not run optimally.

Based on the discussion above, it could be said here that students and schools at SMKN 3 Malang were facing serious problems. That was a tough task that must be done by them, namely realizing online learning. This study provided solutions to the problems discussed above. In addition, this case study produced proven effective learning methods. This strategy would help overcome the problem of distance learning. This study would also explore the benefits and impacts of online teaching methods offered as alternative learning methods in this pandemic situation.

\section{METHOD}

This research method was a qualitative method with a qualitative descriptive form. The researchers' treatment was to fully observe and focus on the behavior of students on classroom rules and procedures that were consistently applied by educators during the learning process, to control behavior and maintain corrected behavior and changed wrong behavior. The research subjects were students of class XII of SMKN 3 Malang.

Data were collected through observation, interviews, and documentation for three weeks to see seven components: readiness to learn, independent learning, working together, attracting students' attention, conveying the essence of learning, motivating students, and evaluating. Each component was measured from 1 to 2, indicating the success and failure of each statement and question. The data presented in tabular form.

\section{RESULTS AND DISCUSSION}

During the observation and data collection, the focus was on seven components to find out educators control students' behavior and become a reference point for students to find out the disciplinary behavior in applied learning.

\section{Table 1}

Questionnaire on the Application of Student Discipline

\begin{tabular}{lccccccc}
\hline Criteria & \multicolumn{3}{c}{ Session } & & & Information \\
\cline { 2 - 6 } & 1 & 2 & 3 & 4 & 5 & \\
\hline Readiness to learn & 12 & 12 & 11 & 11 & 12 & Consistent \\
& VG & VG & VG & VG & VG & \\
\hline Cooperation & 12 & 12 & 11 & 11 & 11 & Consistent \\
& VG & VG & VG & VG & VG & \\
\hline Independent & 11 & 12 & 10 & 11 & 10 & Consistent \\
& VG & VG & VG & VG & VG & \\
\hline
\end{tabular}

(Source: Research Result) VG (very good)

\section{Readiness To Learn}

During the observation, students' learning readiness could be seen from the arrival of readiness, carrying a notebook, wearing full school uniform attributes. While in the learning process, students' learning readiness was measured when listening to the teacher's explanation or not. To control students' attitudes to stay prepared, educators always supported classroom rules to discipline an undesired 
behavior and through five reflection questions at the end of the class. These questions contained an evaluation of the learning process during one meeting to remind and guide deviant behavior so that it did not happen at the next meeting.

\section{Cooperation}

Based on the observations, cooperative training implemented by educators was in the form of dividing students into several groups and determining clear job descriptions in these groups. Students in groups were divided into (1) Moderators, (2) Librarians, (3) Editors, (4) Designers, and (5) Presenters. If students in the group did not do their job well, this would make their friends unable to process the task according to the assigned task. Therefore, students must complete the task correctly so that they could do every task given by the teacher correctly. Through this technique, students could practice emotional control, reduce selfishness, and respect others by doing tasks according to the assigned tasks, so that later when they got the opportunity to transfer tasks, they could carry out their duties well.

To control the attitude of cooperation, educators used class rules in building the value of togetherness. If one member of the group was violated, then all will be penalized in the form of a reduction in group point scores. It aimed to train cohesiveness, togetherness, concern to reprimand each other. The next activity to train cooperation was holding a competition to determine the best group and determine (1) the best moderator, (2) the best librarian, (3) the best editor, (4) the best designer, and (5) the best presenter. Competition was a process of training emotions and togetherness how students shared tasks and supported each other to win because if one of them did not work together, then this team would lose. Could this all proceed with instruction without the sensitivity of the educator to limit, see and direct? Why was the sensitivity of educators very important? Because what was prioritized here was not the result but how the process was. An outcome was just an event but a process to achieve was a more valuable result.

3. Independent

Based on observations, the method applied was able to control the independence of students using daily starter techniques in the class introduction and second training techniques in the learning process. At the beginning of learning, students who were trained for the beginning of the meeting, would see what was written on the daily starter. This was an order for them and must be done according to the instructions given. When students were trained, then at the next meeting, students would be asked independently to carry out the instructions on the daily starter without the guidance of an educator. Second, training techniques in the learning process during practice, students must try to do the tasks given according to the teacher's instructions; if they could not do it, then they were welcome to ask for help from educators.

4. Design And Application Of Instructional Learning Models At SMKN 3 Malang

After explaining the observations and data collection about the impact of the applied learning model, the researcher would explain how the stages in the implementation of the instructional learning model were applied at SMKN 3 Malang. 


\section{Pre-Class Stage}

Students from each class formed groups and divided tasks according to the needs of each group accompanied by the teacher. Besides that, the teacher gave examples of how to do the tasks properly and correctly. At the pre-class stage, the teacher also explained some rules that must be agreed upon. The teacher also did not forget to explain the assessment system that was applied. In this learning model, the teacher applied a points-based assessment system with the following assessment guidelines:

Table 2

Student Assesment

\begin{tabular}{lll}
\hline No. & \multicolumn{1}{c}{ Activities Performed } & Reward Points \\
\hline 1. & Become a Moderator & 25 \\
\hline 2. & Collect Assignments On Time & 10 \\
\hline 3. & Collecting Late Assignments & 5 \\
\hline 4. & Do it yourself assignments & 10 \\
\hline 5. & Complete 1 learning topic & 100 \\
\hline 6. & Become a Group Leader & 20 \\
\hline 7. & Become a Group Librarian & 10 \\
\hline 8. & Become a Group Editor & 15 \\
\hline 9. & Become a Group Designer & 10 \\
\hline 10. & Ask during the presentation session & 5 \\
\hline 11. & Using Javanese Krama variety & 10 \\
\hline \multicolumn{7}{l}{ (Source: Research Results) }
\end{tabular}

\section{Class Stage}

The results of class activities could be seen from the following table, which was a summary of the group work process journals carried out by students:

\section{Table 3}

\section{Presenter's Journal (Group Leader)}

\begin{tabular}{|c|c|c|c|c|}
\hline No & Activity & Exec & ution time & Results \\
\hline 1 & $\begin{array}{l}\text { Dividing the tasks } \\
\text { of each group } \\
\text { member according } \\
\text { to their main task }\end{array}$ & $\begin{array}{l}26 \\
2020\end{array}$ & Oktober & $\begin{array}{l}\text { Task have been evenly divided, the } \\
\text { librarian team has determined the } \\
\text { sources to be used in the paper. }\end{array}$ \\
\hline 2 & $\begin{array}{l}\text { Supervise the } \\
\text { performance of the } \\
\text { librarian team }\end{array}$ & $\begin{array}{l}27 \\
2022\end{array}$ & Oktober & $\begin{array}{l}\text { Changes in the reference sources } \\
\text { used in the paper. The draft paper has } \\
\text { been completed and is ready to be } \\
\text { sumitted to the edtorial team. }\end{array}$ \\
\hline 3 & $\begin{array}{l}\text { Supervise the } \\
\text { performance of the } \\
\text { editorial team }\end{array}$ & $\begin{array}{l}30 \\
2020\end{array}$ & Oktober & $\begin{array}{l}\text { The language used by the librarians } \\
\text { was too random which made it difficult } \\
\text { for the editorial team. The editorial } \\
\text { team had to rearrange the layout of } \\
\text { the paper before converting it to Java. }\end{array}$ \\
\hline 4. & $\begin{array}{l}\text { Supervise the } \\
\text { performance of the } \\
\text { editorial team }\end{array}$ & $\begin{array}{l}1 \\
2020\end{array}$ & November & $\begin{array}{l}\text { The translation went smoothly. The } \\
\text { draft is ready to be sumitted to the } \\
\text { designer team to be used as } \\
\text { powerpoint. }\end{array}$ \\
\hline 5 & Supervise & 1 & November & The powerpoint draft was good and \\
\hline
\end{tabular}




\begin{tabular}{|c|c|c|c|c|}
\hline & $\begin{array}{l}\text { performance of the } \\
\text { designer team \& } \\
\text { PPT consulting }\end{array}$ & 2020 & & $\begin{array}{l}\text { the powerpointwas then consulted } \\
\text { with the teacher to get criticism and } \\
\text { suggestions. }\end{array}$ \\
\hline 6 & $\begin{array}{l}\text { Briefing with the } \\
\text { teacher together } \\
\text { with } \\
\text { members }\end{array}$ & $\begin{array}{l}2 \\
2020\end{array}$ & Nove & $\begin{array}{l}\text { The briefing activity went smoothly } \\
\text { and the group was ready to present } \\
\text { the results of their group work. }\end{array}$ \\
\hline 7 & $\begin{array}{l}\text { Group } \\
\text { presentations and } \\
\text { reflections on } \\
\text { presentation results }\end{array}$ & $\begin{array}{l}5 \\
2020\end{array}$ & November & $\begin{array}{l}\text { Some students were late, making } \\
\text { presentation delayed. But the } \\
\text { presentation still went smoothly. }\end{array}$ \\
\hline
\end{tabular}

(Source: Research Results)

\section{Post-Class Stage}

The presentation results and completion of assignments from each group member were reported in Google Classroom to get feedback on assessment points. At this stage, students also received an evaluation and reflection from the teacher regarding their performance. Students also transferred assignments for the preparation of further material based on reflection and evaluation given by the teacher.

\section{Sound and Tone Management}

One of the salient features of online teaching was the voice of the teacher. The literature showed that effective communication between students and teachers was very important. Keeping the pitch of the voice high and practicing vocal functions such as pauses, variations in intensity were very important. In traditional classroom teaching, body language, eye contact, and physical movement were important teaching tools. However, in online teaching, teachers should focus more on their voice and vocal functions. A recent study showed that speaking softly was beneficial for students. That could help students wrote down important things that conveyed by the teacher (Bao, 2020). It could be suggested in online learning to know about the importance of keeping a low voice and practicing vocal function. That would ensure that the learning process ran effectively, and students could participate in online learning well.

\section{Maintain Critical, Practical and Creative Thinking}

Another thing that needed to be considered in the success of the learning strategy was that the teacher must continue to try to design more creative teaching materials. In other words, students should always be involved in the process of designing the next meeting. A study showed that the development of critical analysis learning materials was very difficult to apply in traditional teaching methods (Persky \& Pollack, 2010). However, in online classes, teachers could assign individuals with realworld case studies. Then, they could ask students to give their ideas and opinions. That would help in developing students' abilities and increase the success rate of online learning.

\section{Flexible Teaching and Assessment Policies}

Due to the lack of high-speed internet connectivity in some areas of Malang, students could not carry out the learning process with the same frequency. Students 
even sometimes were not able to submit assignments and access learning materials provided by the teacher. One of them was a student of SMKN 3 Malang. In the village where he lived, he could only get internet access if he drove for an hour drive to a place where there was a signal; students had to download learning materials and then took them home to observe and study. To overcome this, teachers must show flexibility and gave students extra time. That would assist students in participating in the grading system. SMKN 3 Malang must trained teachers not to pressure students amid a pandemic. On the other hand, teachers must provide full support to students. This support could be in the form of providing access to cheap and easily accessible learning materials and providing an extension of time in the submission of assignments.

\section{Backup Plan for Pandemic Situation}

Due to COVID-19, all classes were switching to online forms. Various problems that could occur were systemic and technical. Institutions sometimes did not have the appropriate resources and equipment to conduct online classes. All of these were significant problems in explaining online classes, such as overloaded servers, lack of computer equipment, and not installing certain software. To overcome these problems, institutions and teachers should always have a backup plan such as plan B or plan $\mathrm{C}$ to solve the problem without causing learning delayed for students.

\section{Organize Cheap and Economical Online Learning and Provide Self-Study Materials}

Before the online session, the teacher must send special readings as material enrichment before the class starts. Teachers could ask students to briefly explain what that they understood after reading the material during the online session. That would help to create discussions in online classes. In addition, students would take part in answering questions if they have read the material. Furthermore, students should be provided with online class notes. This recording would be useful for students who missed or did not understand any part of the learning process carried out.

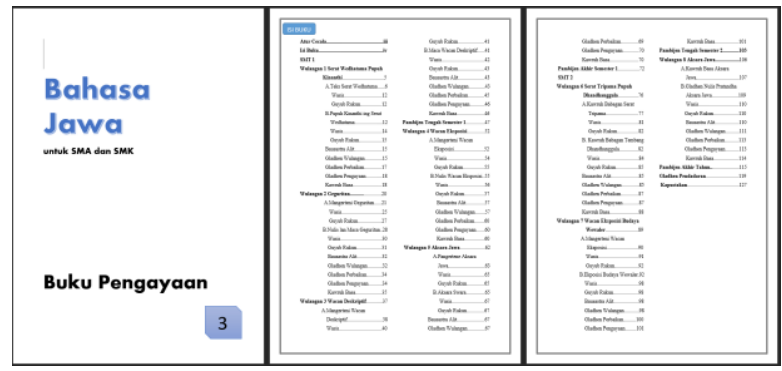

Figure 1 E-book are one form of inexpensive self-study materials that can be pursued

\section{Allocate teaching assistants}

At SMKN 3 Malang, the teachers were not technically trained to accommodate online classes smoothly. Online classes required much greater involvement of technical knowledge than traditional classes. Therefore, the teachers must seek help from one of the students to become a teacher assistant, or in the method applied in this 
study, the teachers must choose a moderator. These teachers' assistants could ensure a successful online session. The teachers should hold a preliminary meeting with their assistant before starting the online session. This would help in managing online learning effectively. In addition, the teachers could allocate their attention to other things. Teachers' assistants could also train students' independence and eased the task of teachers in online classroom learning systems.

\section{CONCLUSION}

This article revealed learning strategies that could be applied to the online learning process. This learning strategy could be practiced by educational institutions similar to how this research was conducted. The approach taken will facilitate the implementation of online education effectively. The case study was developed based on the analysis of online education applied at SMKN 3 Malang. There were several visible impacts from the application of the applied methods, namely (1) readiness to learn, (2) independence, and (3) cooperation. In addition, this study also explained several things that teachers needed to pay attention to in the online learning process at schools, such as sound and tone management, keeping students thinking critically, flexible teaching and assessment policies, preparing backup plans, providing low and economical costs. Learning media, providing teaching materials that could be accessed independently, and allocating teaching assistants.

In addition, this article was a tool to help educational institutions ran online classes smoothly. This study specifically focused on developing countries; SMKN 3 Malang, located in Indonesia's territory, was analogous to describe the state of the online learning process at educational institutions in similar areas. That was to help developing countries implemented and prepared the best learning methods during the COVID-19 pandemic.

\section{REFERENCES}

Bao, W. (2020). COVID -19 and online teaching in higher education: A case study of Peking University. Human Behavior and Emerging Technologies, 2(2). https://doi.org/10.1002/hbe2.191

Jackson, C., Vynnycky, E., \& Mangtani, P. (2016). The Relationship between School Holidays and Transmission of Influenza in England and Wales. American Journal of Epidemiology, 184(9). https://doi.org/10.1093/aje/kww083

Muslimin, A. I., \& Harintama, F. (2020). Online Learning during Pandemic: Students' Motivation, Challenges, and Alternatives. Loquen: English Studies Journal, 13(2). https://doi.org/10.32678/loquen.v13i2.3558

Persky, A. M., \& Pollack, G. M. (2010). Transforming a large-class lecture course to a smaller-group interactive course. American Journal of Pharmaceutical Education, 74(9). https://doi.org/10.5688/aj7409170

Rafiq, F. (2020). Analyzing Students' Attitude towards E-Learning: A Case Study in Higher Education in Pakistan. Pakistan Social Sciences Review, 4(1). https://doi.org/10.35484/pssr.2020(4-i)29 
UNESCO. (2020). Covid-19 Education: From disruption to recovery. Unesco, 19.

Viner, R. M., Russell, S. J., Croker, H., Packer, J., Ward, J., Stansfield, C., Mytton, O., Bonell, C., \& Booy, R. (2020). School closure and management practices during coronavirus outbreaks including COVID-19: a rapid systematic review. In The Lancet Child and Adolescent Health (Vol. 4, Issue 5). https://doi.org/10.1016/S2352-4642(20)30095-X

Weisel, A., \& Dror, O. (2006). School climate, sense of efficacy and Israeli teachers' attitudes toward inclusion of students with special needs. Education, Citizenship and Social Justice, 1(2). https://doi.org/10.1177/1746197906064677

WHO. (2020). Getting your workplace ready for COVID-19. World Health Organization, March.

(C) 2021 by the authors. Submitted for possible open access publication under the terms and conditions of the Creative Commons $\begin{array}{lllll}\text { Attribution } & \text { (CC } & B Y & S A\end{array}$ license (https://creativecommons.org/licenses/by-sa/4.0/). 